\title{
VALVOTTU KOEVAPAUS JA SIIHEN LIITTYVÄ PÄIHDEKUNTOUTUS RIKOKSENTEKIJÖIDEN KUNTOUTUKSESSA ${ }^{1}$
}

Teemu Rantanen: VTT, yliopettaja, Laurea-ammattikorkeakoulu

Minna Lindqvist: VTM, sosiaalityöntekijä

teemu.rantanen@laurea.fi

Janus vol. 26 (1) 2018, 3-20

Tiivistelmä

\section{(J) \\ J a I U S}

VERTAISARVIOITU
KOLLEGALT GRANSKAD
PEER-REVIEWED
wwww.tsv.tiftunnus

Valvottu koevapaus on uudehko rangaistusmuoto,jossa yhdistyy sähköinen ja muu valvonta sekä erilaiset tukitoimet. Artikkelissa kysytään, miten valvottu koevapaus ja siihen liittyvä päihdekuntoutus tukevat rikostaustaisen asiakkaan kuntoutumista. Tutkimuksessa on haastateltu päihdetyöntekijöitä $(n=12)$ ja asiakkaita $(n=12)$. Tutkimus tuo esiin valvotun koevapauden ja siihen liittyvän päihdekuntoutuksen moninaiset myönteiset vaikutukset sekä kuntoutumisen prosessuaalisen luonteen ja muutosmotivaation vähittäisen rakentumisen.Tässä prosessissa paneutuva työntekijä-asiakassuhde on avainasemassa, mutta myös koevapauteen liittyvä valvonta tukee kuntoutumista. Toisaalta aineisto tuo esiin myös rangaistuksellisuuden ja kuntoutuksen jännitteisen luonteen sekä monia kehittämiskohteita. Yleisellä tasolla tutkimus tukee desistanssiteorian ajatusta rikollisuudesta irrottautumisen prosessin pitkäkestoisuudesta ja sosiaalisten olosuhteiden merkityksestä siinä.

\section{JOHDANTO}

Suomalaisista vankeusrangaistukseen tuomituista rikoksentekijöistä valtaosa on päihdeongelmaisia (Joukamaa ym. 2010), ja siten rikoksentekijöiden päihdekuntoutuksen kehittämistä voidaan pitää merkittävänä yhteiskunnallisena haasteena. Tässä artikkelissa tarkastelemme päihdekuntoutusta ja -kuntoutumista osana valvottua koevapautta. Valvottu koevapaus on ehdottoman vankeusrangaistuksen loppuvaiheeseen sijoittuva rangaistusmuoto (enintään $6 \mathrm{kk}$ ), jossa vanki on vankilan ulkopuolella sähköisen ja muun valvonnan alaisena. Valvotun koevapauden avulla pyritään helpottamaan siirtymää vankeudesta vapauteen. Vapautumisen valmistelussa korostuu tarkoituksenmukaisten tukitoimien suunnittelu sekä yhteistyö eri toimijoiden kesken.
Rikostaustaisille asiakkaille on kasaantunut monia ongelmia ja he ovat monessa suhteessa erilaisia kuin muut päihdehoitoon hakeutuneet asiakkaat. Tämä näkyy esimerkiksi runsaampana tartuntatautien ja mielenterveyden häiriöiden esiintyvyytenä, kuolleisuutena ja pienempinä tuloina. Rikosseuraamusasiakkaiden koulutus- ja työllisyystaso on selvästi muuta väestöä heikompi ja valtaosa vankilassa tai yhdyskuntaseuraamuksessa olleista päihdehoidon asiakkaista on työttömiä tai työvoiman ulkopuolella ja vailla toisen asteen koulutusta. (Pitkänen ym. 2016.)

Rikoksentekijöiden kuntoutusta voidaan tutkia eri näkökulmista. Kuntoutuksen vaikuttavuutta on arvioitu vertaamalla tietyn kuntouttavan ohjelman 
läpikäyneiden uusintarikollisuutta verrokkiryhmään, joka ei ole osallistunut tarkasteltavaan ohjelmaan (Tyni 2015). Rikoksentekijöiden kuntoutumista on Suomessa tutkittu vaikuttavuuden ohella myös muun muassa voimaatumisen (Karsikas 2005), osallisuuden (Granfelt 2008), dialogisuuden (Järvinen 2015) ja desitanssin (esim. ViikkiRipatti 2011) näkökulmista. Tämän artikkelin näkökulma paikantuu realistiseen tutkimusotteeseen. Analysoimme haastatteluaineistojen (12 asiakashaastattelu ja 12 työntekijähaastattelua) kautta valvotun koevapauden aikaisen päihdekuntoutuksen vaikutusten rakentumista. Realistisen näkökulman mukaisesti kiinnitämme huomiota valvotun koevapauden ja siihen liittyvän päihdekuntoutuksen aikaansaamiin vaikutuksiin. Lisäksi huomiomme kohdistuu siihen kokonaisvaltaisen prosessiin, joka mahdollistaa vaikutusten syntymisen sekä niihin valvottuun koevapauteen liittyviin kontekstuaalisiin ehtoihin, jotka tukevat tai estävät vaikutusten syntymistä.

\section{Mitä ON VALVOTTU KOEVAPAUS?}

Valvotusta koevapaudesta on ensimmäistä kertaa säädetty vuonna 2006 voimaan tulleessa vankeuslaissa (2005/767). Kokemukset valvotusta koevapaudesta ovat olleet alusta alkaen myönteisiä (Mäkipää 2010) ja sen käyttö on lisääntynyt nopeasti. Vuonna 2016 yhteensä 690 vankia aloitti koevapauden (Rikosseuraamuslaitoksen tilastoja 2016 2017, 35).

Valvottuun koevapauteen sisältyy toimintavelvollisuus, joka voi olla työtä, opiskelua tai muuta toimintakykyä edistävää ja ylläpitävää toimintaa, jota voidaan valvoa (Laki valvotusta koevapaudesta 2013/629, 5\$). Koevapauteen sisältyvä valvonta puolestaan tarkoittaa sähköisen paikannuksen ohella valvontasoittoja, vankilavierailuja ja päihdetestausta sekä tukipartion suorittamia käyntejä kotona, työpaikalla tms. viikko-ohjelmaan merkityssä paikassa. Tukipartiotyötä tekevät ohjaajat ovat Rikosseuraamuslaitoksen virkamiehïa, jotka tukevat rangaistuksen loppuun suorittamisessa ja varmistavat, että rikoksentekijä on hänelle määrätyssä paikassa määrättynä aikana ja päihteettömänä (Rikosseuraamuslaitos).

Valvotun koevapauden taustalla on asteittaisen vapautumisen (Rikosseuraamuslaitoksen strategia 2011-2020) tavoite, jolla pyritään edistämään vapautuvien vankien paluuta yhteiskuntaan. Valvotussa koevapaudessa yhdistyy rankaiseminen, humanistiset ja kuntouttavat näkökulmat sekä managerialistiselle ajattelulle ominainen tehokas riskien hallinta ja päämäärien ja keinojen yksiselitteisyys. Valvotun koevapauden avulla pyritään taloudelliseen säästöön ja vankiluvun vähentämiseen, mutta toisaalta sen taustalla on myös pyrkimys uusintarikollisuuden vähentämiseen, suunnitelmallisen ja ennustettavan rangaistusten täytäntöön panoon ja vapautumiseen sekä yhteiskuntaan integroitumiseen. (Mäkipää 2010, 3-16.)

Valvotun koevapauden on nähty sisältävän myös erilaisia kehittämiskohteita ja jännitteitä. Esimerkiksi Laura Seppäsen ym. (2014, 20-21) mukaan valvotun koevapauden yhteistyöverkostoissa on nähtävissä standardin mukaisen toiminnan sekä yksilöllisen tarpeen mukaisen toiminnan välinen jännite sekä 
toisaalta tiedon luottamuksellisuuden ja hyvän tiedonkulun välinen jännite. Myös valvotun koevapauden keskeisenä elementtinä olevaa sähköistä valvontaa kohtaan on esitetty periaatteellista kritiikkiä. Näkyvien seurantalaitteiden on epäilty leimaavan asiakasta, ja rangaistusta on pidetty syrjivänä, koska se edellyttää rangaistuksen suorittajalta asuntoa sekä työpaikkaa tai muuta rangaistukseen liitettävää toimintaa. Sähköistä valvontaa on arvosteltu toisaalta liian pehmeäksi ja vapaaksi ja toisaalta rangaistuksia käytännössä ankaroittavaksi seuraamusmuodoksi, jolla sosiaalinen kontrolli ulotetaan syvemmälle ihmisten yksityisyyteen ja myös omaisten elämään. (Bülow 2014; Jones 2014; Mäkipää 2010, 49-52.)

\section{VaLVotTu Koevapaus Ja RIKOKSENTEKIJÖIDEN KUNTOUTUS}

Valvotun koevapauden korostuminen liittyy myös kuntoutusparadigman muutoksiin. Rikosseuraamusalalla on 2000-luvulla korostunut what works -ajattelu, joka olettaa, että oikein valitun rangaistusaikaisen toiminnan avulla voidaan vähentää uusintarikollisuuden riskiä. Lähtökohtana on RNR-malli (risk-need-responsivity model; esim. Andrews ym. 2006), joka korostaa riski- ja tarvearvioinnin merkitystä kuntouttavan toiminnan suunnittelussa. Käytännössä what works -ajattelu on tarkoittanut erityisesti kognitiivis-behavioraaliseen näkökulmaan perustuvien ryhmämuotoisten ja strukturoitujen kuntouttavien ohjelmien käyttöönottoa.

Vaikuttavuustutkimukset eivät kuitenkaan ole antaneet täysin yksiselitteistä tukea ohjelmatoiminnalle (esim. Lavikkala 2011; Tyni 2015), ja ohjelmatoiminnan ja RNR-mallin tilalle tai rinnalle on tarjottu rikollisuudesta irrottautumisen prosessia korostavaa desistanssiteoriaa. Desistanssiteorian mukaan uusintarikollisuuden ehkäisyssä on keskeistä rikoksentekijän ja työntekijän keskinäinen suhde sekä huomion kiinnittäminen sosiaalisen tilanteen kohentumiseen (esim. McCulloch 2005; McNeill ym. 2012). Valvottu koevapaus ja desistanssiteoria liittyvät kuntoutuksellisen ajattelutavan muutokseen. Siinä huomio on siirtynyt rangaistuksenaikaisesta toiminnasta lisääntyneessä määrin vapautumisvaiheeseen ja kognitioihin vaikuttamisesta myös sosiaalisen tilanteen huomioimiseen. Esimerkiksi Riitta Granfelt $(2016,80)$ kuvaa desistanssia prosessina, jossa vanki oppii tekemään oikeita valintoja niin sosiaalisten suhteiden kuin toimijuuden osalta. Parhaassa tapauksessa vanki muuttuu köyhästä, päihderiippuvaisesta, työttömästä lainrikkojasta omassa kodissaan asuvaksi työssäkäyväksi tai opiskelevaksi kansalaiseksi. Tässä prosessissa päihteettömyyden tukeminen sekä asunnon löytyminen ja asumisen tuki ovat keskeisessä asemassa.

Rikosseuraamuslaitoksen päihdetyön linjaukset vuosille 2012-2016 (2012) korostavat rikoksettoman elämän valmiuksien tukemista ja sitä, että päihteiden ongelmakäyttö on keskeinen rikollista elämäntapaa ylläpitävä tekijä. Päihdekuntoutuksen näkökulmasta vapautuvat vangit ovat periaatteessa samassa asemassa kuin muutkin kansalaiset ja heillä on päihdehuoltolain (1986/41, 3\$, 7\$) mukainen oikeus tarpeen mukaisiin päihdehuollon palveluihin. Päihdekuntoutus voidaan 
toteuttaa avopalveluna esimerkiksi viikoittaisilla A-klinikkakäynneillä, intensiivisempänä avopalveluna esimerkiksi useana päivänä viikossa toteutettavana ryhmämuotoisena toimintana, ympärivuorokautisena laitosmuotoisena palveluna tai asumispalveluun yhdistettynä. Lisäksi vertaistukitoiminta voi tukea rikoksentekijän päihdekuntoutumista.

\section{TutKimusasetelma}

Malcolm Paynen (2005) mukaan sosiaalityön käytäntöjen tehokkuutta voidaan arvioida vaikuttavuusnäyttöä korostavan evidence-based -lähestymistavan ohella myös konstruktionismin, empowermentin ja kriittisen realismin näkökulmista. Lähestymme tutkimuskohdettamme asiakkaiden ja päihdetyöntekijöiden tulkintojen kautta, mutta emme tyydy tulkinnallisten konstruktioiden analyysiin, vaan oletamme, että eri näkökulmia yhdistämällä voidaan saada tietoa myös vaikuttavista tekijöistä ja kehittämiskohteista. Tutkimusotettamme voisikin luonnehtia realistiseksi. Realistinen näkökulma voi tutkimuksessa tarkoittaa monia eri asioita. Realistinen arviointi (Pawson \& Tilley 1997) korostaa vaikutusten tarkastelun lisäksi vaikuttavien mekanismien ja kontekstuaalisten tekijöiden analyysiä. Tämä tutkimus ei ole varsinaisesti realistinen arviointitutkimus, mutta realistista näkökulmaa mukaillen olemme kiinnostuneet siitä, millaisen kontekstin valvottu koevapaus tarjoaa päihdekuntoutukselle. Kontekstuaalisten tekijöiden ohella kiinnostuksemme kohteena on valvotun koevapauden aikaisen päihdekuntoutuksen koettu vaikuttavuus, mutta ennen kaikkea se vuorovaikutuksellinen prosessi, jossa muutosmotivaatio ja vaikuttavuus rakentuvat. Kysymme, miten valvottu koevapaus ja siihen liittyvä päihdekuntoutus tukevat rikoksentekijöiden kuntoutumista.

Tutkimuksen aineistona ovat päihdetyöntekijöiden $(n=12)$ ja asiakkaiden $(\mathrm{n}=12)$ teemahaastattelut (Liite 1: Taulukko 1). Teemoina olivat: taustatiedot, toiminnan organisointi ja yhteistyö, valvontakäytänteet ja yhteistyö, päihdekuntoutuksen suunnitelmallisuus ja yhteistyö sekä kuntoutusmotivaatio ja toiminnan koettu vaikuttavuus. Haastattelut etenivät teemahaastattelurunkoa noudattaen, mutta haastattelun aikana esitettiin myös spontaanisti tarkentavia lisäkysymyksiä. Ne toteutuivat niissä päihdehoitopaikoissa, joissa haastateltavat työskentelivät, olivat asiakkaina tai olivat olleet asiakkaina. Asiakashaastattelut kestivät 33-75 minuuttia (keskimäärin 58 min.), työntekijähaastattelut 32-91 minuuttia (keskimäärin 61 min.) ja litteroitua haastatteluaineistoa kertyi 398 sivua (1-riviväli).

Laadullinen aineisto voidaan yhtältä ymmärtää faktanäkökulmasta, jolloin aineiston oletetaan antavan tietoa tosiasioista tai toisaalta näytenäkökulmasta, jolloin aineistoa tarkastellaan näytteenä jostain kulttuurisesta tms. kokonaisuudesta (Alasuutari 1999). Tämän tutkimuksen tulkinnallinen lähtökohta paikantuu maltilliseen faktanäkökulmaan, jossa erilaisten näytteiden rinnakkaisen tarkastelun kautta pyritään rakentamaan kokonaiskuvaa valvotun koevapauden ja päihdehoidon yhdistämisestä, sen mahdollisuuksista ja haasteista. Jos sekä asiakkaat että päihdetyöntekijät nostavat esiin saman asian, oletamme, että kyse ei ole pelkästään yksilöiden 
tai joidenkin toimijatahojen subjektiivisista tulkinnoista.

Haastatteluaineistojen luokittelu tapahtui sisällöllisesti. Aineisto pilkottiin muutaman lauseen pituisiin analyysiyksikköihin, joissa esitettiin tietty asia tai kokemus. Sisällöllisesti tai temaattisesti samankaltaiset analyysiyksiköt ryhmiteltiin alaluokiksi, jotka edelleen yhdistettiin yläluokiksi. Aluksi lähtökohtana olivat teemahaastattelurungot, mutta lopullinen luokittelu muodostui aineistolähtöisesti. Asiakashaastatteluaineisto jäsentyi osin asiakasprosessin ajallista logiikkaa mukaillen yläluokkiin: (1) valvotun koevapauden valmistelu, (2) toimeenpanosuunnitelma ja sen valmistelu, (3) prosessin eteneminen, (4) ulkoisen motivaation merkitys, (5) valvontakäytänteet sekä (6) vaikuttavuus. Työntekijähaastattelut puolestaan sisälsivät puhetta (1) valvotun koevapauden aikaisesta päihdekuntoutuksesta hyvänä mahdollisuutena, (2) yhteistyötä haittaavista tiedon puutteista ja toimintakulttuurien eroista, (3) valmisteluvaiheesta, (4) valvontakäytänteistä sekä (5) muutosmotivaatiosta.

Tämän jälkeen asiakas- ja työntekijäaineistot yhdistettiin ja tuloksia suhteutettiin aiempaa rikosseuraamusalan kuntoutusta sivuavaan tutkimukseen sekä tutkimuksen realistiseen viitekehykseen. Näin rakentui kokonaistulkinta, joka nosti esiin ensinnäkin valvotun koevapauden ja siihen liittyvän päihdekuntoutuksen vaikutusten moninaisuuden. Vaikuttavien mekanismien ja vaikutusten rakentumisen näkökulmasta korostui työntekijän persoonan ja paneutuvan asiakassuhteen keskeisyys, valvonnan vaikutukset sekä muutoksen pitkäkestoisuus ja prosessuaalisuus.
Kontekstuaalinen tarkastelu puolestaan nosti keskiöön valvottuun koevapauteen keskeisesti liittyvän rangaistuksellisuuden ja kuntoutuksellisuuden ambivalentin suhteen. Tässä artikkelissa tarkastellaan tuloksia näistä tulkinnallisista näkökulmista käsin. Tuloksia raportoitaessa sitaatteja lyhennettiin poistamalla niistä aiheen kannalta vähemmän merkityksellisiä kohtia (merkitään: ...) ja samalla niitä muokattiin yleiskielisiksi.

Haastateltavat hankittiin päihdekuntoutusyksiköiden kautta ja haastattelut perustuivat vapaaehtoisuuteen. Tutkimusluvat haettiin Rikosseuraamuslaitokselta sekä kultakin päihdehoitoyksiköltä tai sitä ylläpitävältä järjestöltä. Ennen haastattelua haastateltavat allekirjoittivat haastattelusopimuksen, jossa he vakuuttivat olevansa tietoisia haastattelujen tarkoituksesta, raportointitavoista sekä omista oikeuksistaan haastateltavina. Aineistoa analysoitaessa haastattelujen sisältämät tunnistetiedot (henkilöiden ja paikkojen nimet yms.) muutettiin.

\section{VALVOTUN KOEVAPAUDEN JA SIIHEN LIITTYVÄN PÄIHDEKUNTOUTUKSEN VAIKUTUSTEN MONINAISUUS}

Haastateltavat toivat monipuolisesti esiin valvotun koevapauden ja siihen liittyvän päihdehoidon myönteisiä vaikutuksia. Päihteettömyyden, raitistumisen ja rikollisesta elämäntavasta irrottautumisen ohella erityisesti arjen taitojen oppiminen ja vanhemmuuteen saatu tuki korostuivatkin aineistossa keskeisinä myönteisinä vaikutuksina. Muutamat haastateltavat puhuivat myös työllistymisestä ja opiskelun aloittami- 
sesta, jotka olivat päihteettömänä onnistuneet. Päihteettömään arkeen oppiminen ei ole aina ongelmatonta, vaan vapautuva vanki kohtaa monenlaisia haasteita, eikä esimerkiksi paluu perhe-elämään tuomion jälkeen suju aina vangin toivomalla tavalla. Valvottuun koevapauteen kytketty työntekijöiden tuki koettiin kuitenkin tässä tärkeänä. Eräs haastateltava kuvasi prosessia seuraavasti:

V: Moni asia on muuttunut. Nytki on toi työllistyminen ja kaikki toi, se on mennyt älyttömän vaikeaksi. Kaikki pankkitilien avaaminen, jos on luottotiedot mennyt, niin kaikki on mennyt todella hankalaksi. Ihan tommoiset perusasiat, niistä on tehty mielettömän vaikeita... Ja just päihteitten käytöstä mitä ollaan keskusteltu, monessakin suhteessa on ollut hyötyä... Kyllä mä olen onnistunut tossa, että just ehkä toi päihteitten käyttö on pysynyt aika hyvin lapasessa. Ja sitten muutenkin ehkä vähän tasoittunut ihmisenä... Tuossa yhteen väliin mulla oli mielessä, että tietyt asiat pystyy ratkaisemaan väkivallalla. Ehkä sieltä on saanut sellaisia toisia näkökulmia siihen asiaan. Pitää yrittää antaa vaan asioitten olla, et ei tarvitse välttämättä ihan joka asiasta välittää... Ja mä luulen, että perheen kanssa olisi tullut ja vaimon kanssa ongelmia, etenkin just kun pitkällä tuomiolla. Se on ihan eri asia sitten, jos istuu vuoden tai puoli vuotta. Kyllähän ne perhekuviot menevät sitten kumminkin. Se parisuhteen rakentaminen, se alkaa melkein alusta. (H9, asiakas.)

Sitaatissa haastateltava puhuu perheelämän ja parisuhteen uudelleenrakentamisesta pitkän vankilatuomion jälkeen ja tukitoimien merkityksestä tässä. Päihdehoito ja päihteisiin liittyvät keskustelut ovat auttaneet ja haastateltava on saanut onnistumisen kokemuksia, kun päihteiden käyttö on pysynyt hallinnassa. Lisäksi haastateltava puhuu raha-asioiden hoitoon ja työllistymiseen liittyvistä vaikeuksista. Hän on valvotun koevapauden aikana osallistunut myös väkivallan ehkäisyä tukevaan ohjelmaan ja se on tuonut hänelle uudenlaisia näkökulmia asioihin.

Haastateltavat korostivat myös syvempää ja pitkäkestoista muutosta. Muutosta pohdittiin arvomaailman näkökulmasta ja korostettiin rikollisen toiminnan taustalla olevien vaikuttimien purkamista:

V: Se suurin ongelma just tuo arvomaailman kanssa painiminen ja. Se on se, mikä on kaikkein oleellisinta, että imetään tuo arvomaailma tuolta kasvatuslaitoksesta ja vankiloista, ja sit niitten kanssa tapellaan ja noudatetaan semmoisia arvoja, mitkä ei ole realiteeteissa siviilielämään nähden. Oleellista on se, että kuinka pystytään niitten kanssa sitten, soveltamaan sitä arvomaailmaa tänne siviilielämään. Nyt NA:n kautta ja terapeutin kautta ja näitten kautta mä olen hiljalleen purkanut sitä arvomaailmaa sieltä ja sit niitä kipeitä juttuja mitkä on ollut vaikuttavia tekijöitä rikokseen. Ja niitä on ruvettu purkamaa. Ja kyllä se on sanotaanko vasta, et kolme vuotta mennyt ja se on hyvällä alulla, voi sanoo näin, ei se ole missään tapauksessa vielä työstetty läheskään loppuun. (H6, asiakas.)

Sitaatissa tulee näkyviin muutosprosessin hitaus: ajattelun muutos on kolmen vuoden jälkeen vasta "hyvällä alulla". Haastateltavat tarkastelivat valvottua 
koevapautta päihdehoidossa myös uusintarikollisuuden näkökulmasta. Lisäksi he toivat esille, että päihteettömyyden ja uudenlaisen elämäntavan vaikutukset ovat olleet myös sosiaalisen verkoston näkökulmasta merkittävät. Monien haastateltujen asiakkaiden kohdalla sosiaalinen verkosto oli muuttunut ja esimerkiksi NA-ryhmiin kiinnittyminen oli tuonut paljon lisää ystäviä, jotka tukivat muutosprosessissa.

Saamamme tulos on yhtenevä Delphine Vanhaelemeeschin ym. (2014) tutkimuksen kanssa. Heidän mukaansa sähköisellä valvonnalla on monia myönteisiä vaikutuksia, jotka liittyvät muun muassa sosiaaliseen elämään, työhön ja toimeentuloon, vapauden kokemukseen sekä myös psyykkisiin tekijöihin. Rikosseuraamusalan what works -malliin ja siihen perustuvaan vaikuttavuustutkimukseen suhteutettuna tulos avaa uudenlaisia näkökulmia. Ne korostavat vangeille järjestettyjen toimenpiteiden tarkastelua uusintarikollisuuden ehkäisyn ohella myös muun muassa vangin hyvinvoinnin ja sosiaalisen tilanteen näkökulmasta.

TYÖNTEKIJÄN PERSOONAN JA PANEUTUVAN ASIAKASSUHTEEN KESKEISYYS

Haastatteluaineistojemme pieni koko ei mahdollista hoitomuotojen vertailua. Kuitenkin aineistossamme on nähtävissä hyviä esimerkkejä intensiivisen ja ryhmämuotoisen päihdekuntoutuksen hyödyllisyydestä niin avokuin laitoskuntoutuksessa. Monien vankien kohdalla myös vertaistuki on päihdekuntoutumista tukeva elementti. Rikoksentekijän ja työntekijän välinen vuorovaikutus muodostaa yhden kes- keisen tekijän, joka edesauttaa tai ehkäisee kuntoutumisprosessin etenemistä. Haastatellut asiakkaat puhuivat työntekijöistä nimellä ja liittivät heihin positiivisia persoonaan liittyviä määreitä:

V: Jonna Mäkinen, se mun työntekijä, rupesi järjestelemään mun kanssa. Aika nopeasti se sitten lähti käyntiin, et pari kuukautta me vissiin järjesteltiin. Ja sit varmaan se edesauttoi, että asu tuolla asumisyksikös tai tuolla ensikodissa niin, se on kanssa valvottua. On pistokokeita seuloja ja puhallusratsioita. Ja sit kahdeksalta pitää olla siellä. (H13, asiakas.)

Sitaatissa puhutaan "mun työntekijästä’. Tällaisessa puheessa korostuu myös vangin oma osallisuus ja yhdessä tekeminen. Sitaatissa käytetty "me"-sana viittaa siihen, että asiakas ja työntekijä tekevät asioita yhdessä. Toisaalta haastatteluista on havaittavissa se, että työntekijän persoona voi toimia paitsi prosessia eteenpäin vievänä, niin myös sitä haastavana seikkana.

Joissakin tapauksissa vanki koki, että ei saanut minkäänlaista tukea valvotun koevapauden valmisteluun. Haastateltavat korostivat, että valvotusta koevapaudesta oli saatavilla varsin heikosti tietoa ja keskeisenä tietolähteenä toimivat kokeneemmat vangit. Eräs haastateltava korosti, että ilman tätä tietoa ja koevapautta hän olisi jatkanut päihteiden käyttöä tuomionsa jälkeen:

V: Mää en ainakaan ollut ollenkaan tietoinen, että jos en olisi kuullut muilta vangeilta ihan ohimennen sattumoisin ja sitten tarttunut siihen kiinni, en olisi todellakaan tiennyt edes vaihtoehdosta. Ja luultavasti olisin sitten nyt jos- 
sain käyttämässä ellei kuolleena. Tietoa enemmän. (H4, asiakas.)

Sitaatti tuo esiin myös muilta vangeilta saadun tiedon sattumanvaraisuuden: haastateltava oli kuullut valvotusta koevapaudesta sattumalta ja oli sen jälkeen alkanut selvittämään asiaa. Toisaalta osa vangeista kuvasi hyvinkin sujuvia valmisteluprosesseja.

Haastatteluaineistoissamme korostui työntekijän persoonan, paneutumisen ja vuorovaikutuksen tärkeys. Tulos on myös aiemman tutkimuksen valossa uskottava. Esimerkiksi Pekka Saarnio (2001) on havainnut työntekijän interpersoonallisten ominaisuuksien ja vuorovaikutuksen laadun merkityksen asiakkaan hoidossa pysymiseen avopäihdehoidossa. Hedda Giertsenin ym. (2015) tutkimuksen mukaan vangit pitivät työntekijöitä onnistumisen kannalta merkityksellisempänä kuin käytettyjä hoitometodeja. Minna-Kaisa Järvinen (2015, 234-235) puolestaan korostaa, että dialogisuus ja mahdollisuus narratiivisen identiteetin uudelleenrakentamiselle kytkeytyvät asiakastyöntekijäsuhteen muutosvoimaan. Tutkimuksemme mukaan työntekijän paneutuvan otteen, dialogisuuden ja palveluohjauksen merkitys korostuu erityisesti valvotun koevapauden valmistelun yhteydessä, mutta myös koevapauden aikana.

\section{MuUtoksen PROSESSUAALISUUS}

Haastatteluaineistojemme kautta rakentui kuva muutoksen prosessuaalisesta luonteesta. Kuntoutumisprosessi alkoi joidenkin asiakkaiden kohdalla jo vankila-aikaisena päihteettömyytenä ja jatkui siitä katkeamattomana valvotussa koevapaudessa, kuten seuraavasta aineistokatkelmasta tulee esiin:

V: Silloin kun mä olin tämän viimeisen tuomion niin mä käytin huumeita esimerkiksi koko ajan vielä vankilassa... Kun mä pääsin avovankilaan, lopetin sit sen takia, et koska tiesin, et ehkä tarkoitus ei ollut vielä silloin raitistua, mutta et kuitenkin kun niitä testejä pidetään siellä avovankilassa. Mutta sitten pikkuhiljaa ne asiat lähtivät menemään silleen, että tässähän voi yrittääkin jotain muuta. Ja sit kun tuli tämä päihdekuntoutus ja koevapaus, niin sit mä päätin, et mä en enää halua narkata enkä rosvota, et haluun muuttua... Että mul on niin voimakas halu muuttua vaan. Kun aikaisemmin elämässä oli silleen, että toivoi lähinnä, että kuolisi pois, niin nyt on tullut hirveä elämänhalu. Että kun saisi elää mahdollisimman pitkään ja tehtyä tässä yhteiskunnassa vielä tai annettua sen oman panoksen. (H18, asiakas).

Vaikka raitistuminen ei aluksi ollutkaan haastateltavan tavoite, päihteettömyys avovankilassa käynnisti ajatusprosessin, joka johti muutoshaluun. Alkanutta muutosprosessia tuki valvotun koevapauden aikainen tiivis päihdehoito. Asiakkaan elämähalu heräsi ja vähitellen syntyi myös halu osallistua yhteiskuntaan ja tehdä jotain tärkeää, ja niinpä haastateltava oli haastatteluhetkellä ollut jo kolmisen vuotta raittiina. Tällaisessa kuntoutumis- tai raitistumisprosessissa mikään yksittäinen tekijä ei ole muutoksen aiheuttaja, vaan muutokset ovat tapahtuneet vähitellen.

Joidenkin asiakkaiden kohdalla valvottu koevapaus näyttäytyi "ainutlaatuisena mahdollisuutena". Erityisesti työntekijät 
korostivat, että valvottu koevapaus toimii tukena hoitoon ohjautumisessa ja mahdollistaa sen, että päihdepalvelujen piiriin saadaan myös asiakkaita, jotka eivät tulisi muuten kohdatuiksi:

V: Ei ehkä näitä ihmisiä saataisi koskaan mihinkään mielenterveyspalveluihin tai A-klinikoille, ehkä 20-30:n vuoden kuluttua... Ei välttämättä nämä vankilassa olevat ihmiset, joilla on ammattitaitona myös vältellä, ehkä osittain viranomaisia ja kontrollia ja ei. Itse pitää pärjätä, apua ei pyydetä ja muuta. Ei heillä ole mitään muuta paikkaa kuin vankila tai tämän kaltaiset paikat, joissa me kohdataan näitä ihmisiä... Tämä on todella hyvä juttu. Voi olla monta mieltä, että miksi ihmiset tulee koevapauteen ja onko se ensisijainen, että haluaa hoitaa päihdeongelmaa tai kuntoutua. Mutta musta se ei ole olennainen kysymys kyllä siinä vaiheessa yhtään. Se on ainutlaatuinen mahdollisuus. (H15, päihdetyöntekijä.)

Haastateltava viittaa puheessaan siihen, että valvottu koevapaus tuo päihdehoitoon myös asiakkaita, joiden ensisijaisena motiivina ei ole päihdeongelman hoito tai kuntoutuminen. Haastateltava ei pitänyt asiaa olennaisena, mutta haastatteluaineistossa tuli esiin myös siihen liittyviä haasteita. Valvotun koevapauden myötä päihdehoitoon saattaa tulla asiakkaita, jotka eivät ole tottuneet puhumaan elämästään ja päihdeongelmastaan. Tällöin asiakkaalta edellytetään "kuntoutuskulttuurin oppimista". Tämä puolestaan on pitkällinen prosessi, jolloin haasteeksi nousee valvotun koevapauden lyhyt kesto. Haasteista huolimatta valvottuun koevapauteen sisällytetty päihdekuntoutus on mahdollisuus hoitoon kiinnittymiseen ja muutokseen.
Haastatteluaineisto toi näkyväksi esimerkkejä, joissa henkilö raitistui valvotun koevapauden ja siihen liittyvän päihdehoidon aikana vuosia tai jopa vuosikymmeniä kestäneen päihteiden ongelmakäytön jälkeen. Heidän kohdallaan muutosmotivaatio syntyi vasta kuntoutusprosessin kuluessa, kun asioiden pohdinta päihteettömästi mahdollistui. Vaikka aluksi vangin tavoitteena oli ollut vain halu suorittaa vankeustuomio loppuun siviilissä, valvotun koevapauden ja päihdekuntoutuksen edetessä myös raittiuden hyvät puolet tulivat yhä vahvemmin esiin.

Päihdetutkimuksen piirissä on korostettu sisäisen motivaation tärkeyttä hoitoon kiinnittymisen ja hoidon tuloksellisuuden kannalta. Esimerkiksi Cameron Wild ym. (2006) ovat verranneet toisiinsa sisäistä motivaatiota (esim. halu muutoksiin elämässä), sisäistettyä ulkoista motivaatiota (esim. häpeä ja syyllisyys) ja ulkoista motivaatiota (esim. sosiaalinen paine). Heidän tutkimuksensa mukaan sisäinen muutosmotivaatio on päihteiden käytön vähentämisen kannalta olennainen, kun taas ulkoisella motivaatiolla ei ole merkitsevää vaikutusta päihteiden käyttöön tai käytön vähentämisen koettuihin hyötyihin tai kustannuksiin. Aineistomme tuo näkyviin esimerkkejä siitä, että myös rangaistuksen pelkoon liittyvä ulkoinen motivaatio voi olla raitistumis- ja kuntoutumisprosessissa jossain vaiheessa jopa sitä edistävä tekijä. Tulos vastaa hyvin Amy Kirbyn ym. (2011, 23) näkemystä, jonka mukaan motivaatio ja muutosvalmius vaikuttavat hoitosuhteen laatuun. Niiden vaikutus kuitenkin vaihtelee merkittävästi intervention aikana tavoitteiden ja painopisteiden muuttu- 
essa, ja motivaatioon ja muutosvalmiuteen voidaan myös vaikuttaa.

Tutkimuksemme tukee lisäksi näkemystä siitä, että myös velvoitettu tai rangaistukseen olennaisesti liittyvä hoito voi olla päihteitä käyttävän rikoksentekijän näkökulmasta hyödyllistä. Tulos on kiintoisa, koska aiemmat tutkimukset ovat antaneet ristiriitaisen kuvan rangaistuksen ja kuntoutuksen yhdistämisen hyödyllisyydestä. Esimerkiksi David A. Brightin ja Kristy A. Martinen (2013) meta-analyysi kohdentui 111:een vuosina 19962011 ilmestyneeseen tutkimukseen, jotka käsittelivät rangaistuksen ja päihdekuntoutuksen yhdistämistä ja suuri osa tarkastelluista tutkimuksista osoitti, että velvoitetulla hoidolla on myönteisiä vaikutuksia sekä päihteiden käyttöön että rikollisuuteen. Kuitenkaan kaikissa tutkimuksissa näitä vaikutuksia ei havaittu, ja joissakin tutkimuksissa havaittiin myös negatiivisia vaikutuksia. Kaiken kaikkiaan saamamme tulokset ja aiemmat tutkimukset antavat kuitenkin syyn olettaa, että valvottuun koevapauteen sisältyviä velvoite-elementtejä ei voida pitää sinällään päihdehoidon tuloksellisuutta ehkäisevinä tekijöinä. Muutosmotivaatio voi syntyä ja kehittyä myös rangaistukseen liittyvän hoidon aikana.

\section{VALVONNAN KUNTOUTTAVA MERKITYS JA SEN HAASTEET}

Valvottuun koevapauteen liittyvä Rikosseuraamuslaitoksen suorittama valvonta näyttäytyy sekä työntekijä- että asiakasaineistossamme pääosin kuntoutusta tukevana. Haastateltavien mukaan viikkoaikataulu ja valvonta varmistavat päihteettömyyden sekä sen, että päihdehoidossa voidaan keskittyä kuntouttavaan toimintaan. Tarkoin määritelty viikko-ohjelma tuo arkeen säännönmukaisuutta, joka monien asiakkaiden kohdalla mahdollistaa myös ihmissuhteiden ja perhe-elämän uudelleen rakentamisen sekä joidenkin kohdalla työelämään palaamisen.

Toisaalta haastatteluissa tuli esiin valvottuun koevapauteen liittyvien aikataulujen haasteellisuus. Esimerkiksi myöhään illalla päättyvä vertaistukiryhmä aiheutti ongelman, miten ehtiä vaadittuun aikaan kotiin. Haastateltavat ilmaisivat myös pelkoa siitä, muistavatko soittaa vaadittuun aikaan. Perheelliset vangit puolestaan pohtivat sitä, miten tukipartion kontrollikäynnit vaikuttavat normaaliin perheen arkeen ja aiheuttavatko ne muiden perheenjäsenten leimaantumista. Pelättiin myös sitä, että lapset joutuvat kiusatuksi koulussa, jos muut saavat tietää heidän isänsä olleen vankilassa. Eräs asiakas pohti jalkapantaan liittyvää leimaantumista lapsen kanssa tapahtuvien uimahallikäyntien yhteydessä ja pohti, mitä ulkopuoliset ajattelevat lapsesta, kun huomaavat tämän isän valvontalaitteen. Kaiken kaikkiaan pantaa pidettiin kuitenkin asiaankuuluvana, kuten seuraavassa sitaatissa tulee esiin:

V: Kyllähän se panta tietysti aika häiritsevä on. Mut ei se, ei niistä nyt sen enempää. Ja mun mielestä se on vähän, toisaalta kun mähän olin silloin kumminkin vanki. Toinen vaihtoehto olisi ollut se että mä olisin ollut Vankilassa. (H9, asiakas.)

Sitaatti kuvastaa monien haastateltavien jakamaa ajatusta siitä, että panta 
häiritsee jonkin verran arkea, mutta sen olemassaolo hyväksytään, koska ymmärretään oma asema vankina.

Aiemmat kansainväliset tutkimukset antavat kohtuullisen myönteisen kuvan sähköisen valvonnan vaikuttavuudesta uusintarikollisuuteen, joskaan tulokset eivät ole täysin yksiselitteisiä (Marklund \& Holmberg 2009, Schwedler \& Woessner 2017). Myös tutkimusaineistojemme kautta muodostunut kuva on samansuuntainen, vaikka tutkimuksemme ei suoranaisesti tarkastelekaan sähköisen valvonnan vaikuttavuutta. Sitä vastoin aiemmista tutkimuksista (Bülow 2014; Jones 2014) poiketen sähköisen valvonnan hyväksyttävyyteen liittyvät ongelmat eivät tämän tutkimuksen tuloksissa nousseet esille lukuun ottamatta pelkoa omaisten leimaantumisesta.

\section{RANGAISTUKSELLISUUDEN JA KUNTOUTUKSEN AMBIVALENSSI}

Sekä asiakkaat että päihdetyöntekijät toivat esiin lukuisia yhteistyön ongelmakohtia, jotka liittyivät valvotun koevapauden ja siihen liittyvän päihdehoidon prosessin eri vaiheisiin. Varsinkin avokuntoutuksen valmisteluvaiheen yhteistyö oli usein vähäistä. Ääritapauksessa valvotussa koevapaudessa oleva vanki tulee A-klinikkakäynnille ja työntekijä kuulee tällöin ensimmäisen kerran, että ko. päihdehoito on osa asiakkaan toimintavelvollisuutta. Edelleen myös itse työskentelyvaiheeseen ja sen päättämiseen kaivattiin lisää yhteistyötä. Vankien näkökulmasta keskeiseksi haasteeksi nousi tiedon saanti valvotusta koevapaudesta ja päihdekuntoutuk- sesta vankilassaoloaikana. Vangin osallistuminen valvotun koevapauden ja päihdehoidon suunnitteluun ei myöskään kaikissa tapauksissa toteudu.

Tulokset toivat näkyviin myös joitakin Rikosseuraamusalaitoksen suorittamaan valvontaan liittyviä epäkohtia ja yhteistyön haasteita, jotka näkyivät muun muassa päällekkäisenä toimintana.Yhtenä esimerkkinä tästä aineistossa tuli esiin laitosmuotoisessa tai muussa ympärivuorokautisesti tuetussa päihdekuntoutuksessa olevien asiakkaiden kaksinkertainen valvonta, kun sekä Rikosseuraamuslaitos että päihdehoitolaitos testaavat erikseen päihteettömyyttä ja kontrolloivat asiakkaiden liikkumista. Asia herätti päihdetyöntekijöissä tunteen luottamuksen puutteesta:

V: Meillä on kuitenkin niin, suhteellisen isot vaatimukset tässä [naurahtaa] meidän tässä asumisyhteisössä siitä, että kaikki tietää kyllä varmastikin lähestulkoon koko ajan missä toinen, liikkuu. Niin se ehkä.Vähän tuli semmoisia fiiliksiä aina välillä että vähä meitä aliarvioidaan [naurahtaa] meidän kykyä. Tai ei uskota että, me nyt oikeasti tiedettäisi tai et yhteisö tietää, missä yhteisön jäsen liikkuu. (H11, päihdetyöntekijä.)

Hämmennystä aiheuttivat myös tapaukset, joissa tukipartio oli käynyt testaamassa asiakkaan päihteettömyyden kesken viikko-ohjelman mukaista kuntouttavaa ryhmää. Valvotun koevapauden aikaista päihdekuntoutusta haittaavat ajoittain myös kahden erilaisen toimintakulttuurin ristiriitaisuudet ja niihin liittyvät haasteet. Retkahdustapaukset ja -epäilyt nostivat siten esiin periaatteellisemman pohdinnan hoidollisen otteen ja rangaistuksellisuuden 
välisestä suhteesta. Haastateltavilla oli kokemuksia tapauksista, joissa vankila oli reagoinut äärimmäisen voimakkaasti päihde-epäilyyn:

V: Jos esimerkiksi meillä on joku päihde-epäily ja me ilmoitetaan vankilaan, että voisiko tää tsekata tämän ihmisen ja kattoa, niin se voi pahimmillaan sitten näyttäytyy sillä, että sinne taloon tehdään rynnäkkö ja mies riisutaan alasti ja viedään suljettuun taloon. Ja se voi olla se kaveri siellä pari kolme viikkoa eristyksissä odottamassa sitä, että saadaan seulavarmistus. (H15, päihdetyöntekijä.)

Sitaatissa rakennetaan kuvaa ylimitoitetuista kontrollitoimenpiteestä, joka johtaa asiakkaan kannalta kohtuuttomaan lopputulokseen. Tällaiset esimerkit saavat päihdetyöntekijät myös varovaiseksi sen suhteen, miten asioista voi kertoa ja kenelle. Samalla korostuu pitkäkestoisen yhteistyön ja yhteisen linjan löytymisen merkitys. Haastateltavien mukaan olisi tärkeää, että erilaiset epäonnistumiset käsiteltäisiin siten, että asiakas voisi oppia niistä.

Rikosseuraamusten täytäntöönpanon näkökulmasta päihdekuntoutukseen liittyykin tietty ambivalenssi. Rikosseuraamuslaitoksen päihdetyön linjauksissa 2012-16 (2012) toisaalta korostetaan päihdekuntoutuksen keskeistä merkitystä uusintarikollisuuden ehkäisyssä, mutta toisaalta todetaan yksiselitteisesti, ettei rikosseuraamuslaitos ole kuntoutusorganisaatio vaan sen ensisijainen tehtävä on rangaistusten täytäntöönpano (s. 5). Hallituksen esityksessä valvotusta koevapaudesta (HE 140/2012 vp, 32) korostetaan, että valvotun koevapauden aikaiseen päihteiden käyttöön suhtaudutaan nimenomaan rikkomuksena ja kun kyse on huumausaineista, asian käsittely noudattaa rikoslakia. Toteutettaessa vankien päihdekuntoutusta vankilan ulkopuolella ollaankin tekemisissä kahden erilaisen toimintakulttuurin ja työskentelytavoitteen kanssa. Vankilatyöntekijöiden ja tukipartioiden työ määrittyy rikosseuraamusalan lähtökohdista käsin, jolloin keskiössä on rangaistuksen lainmukainen täytäntöönpano ja uusintarikollisuuden ehkäisy, kun taas päihdehoidon kannalta kyse on asiakkaan tarpeen mukaisesta päihdekuntoutuksesta. Vaikka aineistojemme mukaan valvonta näyttääkin toimivan kuntoutumista tukevana, siihen liittyy myös periaatteellisia ja käytännöllisiä haasteita.

\section{JонторёÄтӧKSIÄ}

Tutkimusaineistojen kautta rakentui kuva, jonka mukaan valvottu koevapaus ja siihen liittyvä päihdekuntoutus tukevat päihdeongelmaisten rikoksentekijöiden kuntoutumista. Niillä näyttäisi olevan moninaisia myönteisiä vaikutuksia, jotka eivät rajoitu pelkästään uusintarikollisuuden ehkäisyyn. Tutkimusaineistomme, desistanssi-keskustelu ja suomalainen sosiaalityön viitekehyksestä lähtevä asiakas-työntekijäsuhteeseen kohdentuva tutkimus rakentavat varsin yhtenäistä kuvaa kuntouttavan työn vaikuttavuudesta. Pelkkä kuntouttaviin ohjelmiin ja ammatillisiin työmenetelmiin keskittyminen ei riitä, vaan olennaista on huomion kiinnittäminen asiakkaan kokonaistilanteeseen ja kuntouttavan työn vuorovaikutukselliseen luonteeseen. Asiakas-työntekijä-suhde on tällöin avainasemassa. 
Minna-Kaisa Järvisen $(2015,233)$ aineistossa desistanssi-prosessin näkökulmasta keskeinen käännekohta liittyy usein päihteiden käytön lopettamiseen. Päihteiden käytön lopettaminen mahdollistaa rehellisyyden asiakastyöntekijäsuhteessa. Edelleen hän tuo esiin, että asiakas voi olla valmis yhteistyöhön ennen kuin hän on valmis muutokseen. Yhteistyövalmius antaa valmiuksia myös muutostyöskentelyyn. Vaikka sisäinen muutosmotivaatio onkin päihdehoidon tuloksellisuuden näkökulmasta keskeinen (Wild 2006), se voi rakentua kuntoutumisprosessin $\mathrm{ku}-$ luessa, kun asioiden käsittely päihteettömästi mahdollistuu.

Aiemmissa tutkimuksissa on saatu hyviä tuloksia päihdehoidon yhdistämisestä rangaistukseen, joskin tutkimustulokset ovat osin ristiriitaisia (Bright \& Martine 2012). Tämän tutkimuksen valossa rikosseuraamukseen liittyvän valvonnan ja päihdekuntoutuksen yhdistämistä voidaan pitää perusteltuna. Yhtenevästi aiempien tutkimusten kanssa (esim. Giertsen ym. 2015) päihdehoidossa olleet asiakkaat eivät juurikaan esittäneet kritiikkiä heihin kohdistettua kontrollia kohtaan, vaan pitivät sitä rangaistukseen kuuluvana osana. Koevapauteen liittyvä päiväohjelma ja valvonta näyttäytyvät aineistossa kuntoutusta tukevina; ne varmistavat asiakkaiden päihteettömyyden sekä sen, että päihdehoidossa voidaan keskittyä kuntouttavaan toimintaan. Toisaalta aineistossa nousi esiin rangaistuksellisuuden ja kuntoutuksen ambivalentti suhde, mikä voi olla haaste myös paneutuvan työotteen omaksumisen näkökulmasta.

\section{KÄYTÄNNÖN KEHITTÄMISKOHTEITA}

Tutkimuksessa tuli esiin valvottuun koevapauteen liittyviä kehittämiskohteita, jotka paikantuivat yhteistyöhön, vankien tasa-arvoiseen kohteluun, valvonnan kuntoutuksellisten elementtien vahvistamiseen sekä työntekijä-asiakassuhteen luonteeseen. Yhteistyön haasteet koskevat valvotun koevapauden valmistelua ja päihdehoidon suunnittelua sekä valvotun koevapauden aikaista toimintaa ja sen päättymisvaihetta. Varsinkin avokuntoutuksen kohdalla koevapauden valmisteluvaiheen yhteistyö oli usein vähäistä tai jopa olematonta. Yhteistyötä vaikeuttavat myös työntekijöiden tiedon puutteet sekä toimintakulttuurien erot. Yhteisen ymmärryksen rakentuminen ja tarkoituksenmukaisen koevapaussuunnitelman laatiminen edellyttävät säännöllistä vuoropuhelua, jossa kaikkien osapuolten näkökulmat huomioidaan. Tämä vaatii paitsi ammatillisen yhteistyön kehittämistä rikosseuraamuslaitoksen, kuntien ja päihdehoitoyksikköjen välillä, niin myös halua ja kykyä tehdä yhteistyötä vangin ja omaisten kanssa.

Tutkimus osoittaa myös sen, että valvotun koevapauden näkökulmasta vangit eivät ole kaikilta osin tasa-arvoisessa asemassa keskenään. Työntekijöiden työtapojen ja vankiloiden väliset erot ovat huomattavia. Epäyhtenäisyyttä oli nähtävissä sekä valvotun koevapauden valmisteluprosessissa, valvotun koevapauden rangaistusajan suunnitelmissa että erilaisissa lupamenettelyissä. Jotkut vankiloiden työntekijöistä tukivat voimakkaasti valvottuun koevapauteen pyrkivää vankia, mutta joidenkin vankien oli erittäin vaikea saada minkään- 
laista tietoa tai tukea koevapauden valmisteluun.

Uusintarikollisuuden ehkäisyn kannalta olisi keskeistä vahvistaa valvotun koevapauden ja erityisesti tukipartiotoiminnan kuntoutuksellisia elementtejä. Parhaimmillaan tukipartiot toimivat hyvänä tukena asiakkaalle ja hänen päihteettömyydelleen. Esimerkiksi viikko-ohjelman mukaisten kuntouttavien ryhmien aikaan ajoittuvat ja näkyvästi toteutetut valvontakäynnit voivat kuitenkin toimia myös vankia leimaavina ja kuntoutumista haittaavina. Osalle päihdetyöntekijöistä tukipartiotoiminta oli jäänyt etäiseksi ja irralliseksi osaksi kokonaisuutta, ja lisää yhteistyötä tukipartioiden kanssa kaivattiin.

Tutkimuksessa tuli esiin työntekijän persoonallisen otteen ja tuen merkitys. Kuntoutumisprosessin näkökulmasta olisi tärkeää, että vangilla olisi vankilassa tukenaan valvotun koevapauden valmisteluun paneutuva ja vankia tukeva vankilan työntekijä,jolla on vastuu myös verkostoyhteistyön koordinoinnista. Vankiloiden palveluohjausta ja lähityötä edelleen kehittämällä olisi mahdollista päästä siihen, että valvottu koevapaus ja siihen liittyvä päihdekuntoutus tukisi entistä paremmin vangin kokonaisvaltaista kuntoutumista ja siviiliin paluuta.

\section{PohdintaA}

Suppeahkon laadullisen aineiston pohjalta ei tietenkään voida tehdä yleistäviä johtopäätöksiä. Esimerkiksi havainnot valvonnan kuntoutusta tukevista vaikutuksista ja muutosmotivaation vähittäisestä rakentumisesta päihdekun- toutuksen aikana koskevat yksittäisiä vankeja, eikä tutkimus kerro tällaisten ilmiöiden määrällisestä esiintyvyydestä. Toisaalta keskeiset ydintuloksemme, kuten esimerkiksi valvotun koevapauden myönteisten vaikutusten moninaisuus, valvonnan positiiviset vaikutukset ja valvottuun koevapauteen liittyvät yhteistyön ja tiedonkulun haasteet, tulevat yhtenevästi näkyviin sekä asiakasettä työntekijähaastatteluissa. Edelleen tulkintojen uskottavuutta lisää se, että aineiston luokittelu ja tulkinta tehtiin kahden asioita erilaisesta positiosta tarkastelevan tutkijan yhteistyönä.

Sosiaalityön tutkimuksen piirissä on 2000-luvulla korostettu vaikuttavien ja näyttöön perustuvien työmenetelmien ja käytäntöjen merkitystä. Rikosseuraamusalalla tämä korostus on ollut vielä selkeästi vahvempaa. Painotuksen taustalla on ollut toimintakulttuuristen tekijöiden ohella what works -paradigma, joka on korostanut strukturoituja toimintaohjelmia ja nimenomaan uusintarikollisuuden ehkäisyä kuntoutuksen päämääränä (Rantanen \& Toikko 2014). Siirtyminen toimintaohjelmia korostavasta what works -ajattelusta rikollisuudesta irrottautumista korostavaan desistanssi-paradigmaan merkitsee muutosta myös rikosseuraamusalan organisaatiokulttuurissa. Rikosseuraamuslaitoksen laatututkimus on tuonut esiin, että paneutuvan ja välittävän työotteen sovittaminen rikosseuraamusalan muodolliseen ja rangaistuksellisen täytäntöönpanon vaatimuksiin ei ole ongelmatonta (Linderborg ym. 2015, 143). Kuntouttavaa asiakassuhdetta painottavan työotteen laajamittainen omaksuminen suomalaisella rikosseuraamusalalla edellyttääkin kulttuurista muutosta. 
Muutos koskee myös rikoksentekijöiden kuntoutuksen arvioinnin metodologiaa. Kun kuntoutus ymmärretään strukturoidun toiminnan sijasta yksilöllisenä prosessina ja sen tulokset ymmärretään laajemmin kuin pelkästään uusintarikollisuuden näkökulmasta, perinteinen kvantitatiivinen vaikuttavuustutkimus joutuu huomattaviin vaikeuksiin. Yhtenä mahdollisuutena on siirtyminen realistiseen näkökulmaan, jossa huomio kiinnittyy paitsi lopputulokseen myös siihen kokonaisvaltaiseen prosessiin, joka mahdollistaa vaikutusten syntymisen, sekä niihin kontekstuaalisiin ehtoihin, jotka tukevat tai estävät vaikutusten syntymistä.

Valvotun koevapauden kehittämisen haasteellisuutta lisää se, että koevapauden taustalla on erilaisia ja jopa keskenään ristiriitaisia kriminaalipoliittisia näkökulmia (Mäkipää 2010, 5-6). On asiakkaiden kuntoutusprosessin näkökulmasta ongelmallista, jos valvottuun koevapauteen liittyvä valvonta jäsentyy rankaisemista painottavan repressiivisen lähtökohdan tai puhtaasti manageristisen logiikan mukaisesti. Vaikka kansainvälisesti sähköisen valvonnan yleistymisen voidaan katsoa osin liittyvän uusliberalistiseen kriminaalipolitiikkaan (Nellis 2014), suomalaisen valvotun koevapauden järjestelmän vahvuus perustuu pitkälti valvonnan ja kuntoutuksellisten elementtien tarkoituksenmukaiseen yhdistämiseen. Parhaimmillaan valvottu koevapaus yhdistää angloamerikkalaista uusintarikollisuuden ehkäisyyn tähtäävää rikoksentekijöiden kuntoutusta korostavaa perinnettä ja pohjoismaista asiakkaan sosiaalista kontekstia korostavaa hyvinvointivaltiollista perinnettä.

\section{VIITTEET}

1 Tutkimus on osa Rikosseuraamusalan tutkimus- ja kehittämismäärärahoista rahoitettua Laurea-ammattikorkeakoulun ja A-klinikkasäätiön toteuttamaa Valvottu koevapaus päihdehoidossa -hanketta

\section{KirJallisuus}

Alasuutari, Pertti (1999) Laadullinen tutkimus. Kolmas painos. Tampere:Vastapaino. Andrews, D. A. \& Bonta, James \& Wormith J. Stephen (2006) The Recent Past and Near Future of Risk and/or Need Assessment. Crime \& Delinquency 52 (1), 7-27.

Bright, David A \& Martire, Kristy A (2013) Does Coerced Treatment of SubstanceUsing Offenders Lead to Improvements in Substance Use and Recidivism? A Review of the Treatment Efficacy Literature. Australian Psychologist 48 (1), 69-81.

Bülow, William (2014) Electronic Monitoring of Offenders: An Ethical Review. Science and Engineering Ethics 20 (2), 505-518.

Giertsen, Hedda \& Nylander, Per Åke \& Asmussen Frank, Vibeke \& Kolind, Torsten \& Tourunen, Jouni (2015) Prisoners experiences of drug treatment and punishment in four Nordic countries. Nordic Studies on Alcohol and Drugs 32 (2), 145-164.

Granfelt, Riitta (2008) Osalliseksi omaan elämään -Work out -ohjelma nuoren vangin tukena. Rikosseuraamusviraston julkaisuja 4/2008. Helsinki: Rikosseuraamusvirasto.

Granfelt, Riitta (2016) Vankilasta desistanssipolun kautta kotiin. Teoksessa Kirsi Juhila \& Teppo Kröger (toim.) Siirtymät ja valinnat asumispoluilla. SoPhi, Jyväskylän yliopisto, 60-84.

HE 140/2012 vp. Hallituksen esitys eduskunnalle valvottua koevapautta koskevaksi lainsäädännöksi.

Jones, Richard (2014) The electronic monitoring of offenders: penal moderation or penal excess? Crime, Law and Social 
Change 62 (4), 475-488.

Joukamaa, Matti \& työryhmä (2010) Rikosseuraamusasiakkaiden terveys, työkyky ja hoidontarve. Perustulosraportti. Rikosseuraamuslaitoksen julkaisuja 1/2010, Helsinki: Rikosseuraamuslaitos.

Järvinen, Minna-Kaisa (2015) Asiakastyöntekijäsuhde rikosseuraamusalalla. Dialoginen arviointi tiedon tuotannon tapana. Väitöskirja. Acta Universitatis Tamperensis 2013. Tampere: Tampere University Press.

Karsikas, Vuokko (2005) Selvinpäin olosta tulee hyvä fillis. Päihdeongelmaisten vankien voimaantuminen. Rikosseuraamusviraston julkaisuja 3/2005, Helsinki: Rikosseuraamuslaitos.

Kirby,Amy \& McSweeney, Tim \& Turnbull, Paul \& Bhardwa, Bina (2011) Engaging substance misusing offenders: A rapid review of the substance misuse treatment literature. London: Institute for Criminal Policy research.

Laki valvotusta koevapaudesta 2013/629. Finlex.

Lavikkala, Raino (2011) Vaikuttavan rikosseuraamustyön kysymyksiä. Teoksessa Raino Lavikkala \& Henrik Linderborg (toim.) Rikosseuraamustyön kehittämisen kysymyksiä. Rikosseuraamusalan koulutuskeskus. Acta Poenologica 2/2011. Vantaa: Rikosseuraamusalan koulutuskeskus, 93-140.

Linderborg, Henrik \& Blomster, Peter \& Muiluvuori, Marja-Liisa \& Tyni, Sasu \& Laurila, Tuomas (2015) Yhtenäinen organisaatio - yhtenäinen laatu? Tutkimus vankeuden ja yhdyskuntaseuraamusten laatutekijöistä Rikosseuraamuslaitoksessa. Rikosseuraamuslaitoksen julkaisuja 2/2015. Helsinki: Rikosseuraamuslaitos.

Marklund, Fredrik \& Holmberg, Stina (2009) Effects of early release from prison using electronic tagging in Sweden. Journal of Experimental Criminology 5 (1), 41-61.

Mason, Jennifer (1996) Qualitative researching. London: Sage.

McCulloch, Trish (2005) Probation, social context and desistance: Retracing the relationship. Probation Journal. The Journal of Community and Criminal Justice, 52 (1), 8-22.

McNeill, Fergus \& Farral, Stephen \& Ligh- towler, Claire \& Maruna, Shadd (2012) How and why people stop offending: Discovering desistance. IRISS Insights, no.15. Glasgow: The Institute for Research and Innovation in Social Services. Mäkipää, Leena (2010) Valvotun koevapauden toimeenpano ja sovellettavuus. Oikeuspoliittisen tutkimuslaitoksen tutkimuksia 249, Helsinki: Oikeuspoliittinen tutkimuslaitos.

Nellis, Mike (2014) Understanding the electronic monitoring of offenders in Europe: expansion, regulation and prospects. Crime, Law and Social Change 62 (4), 489-510.

Pawson, Ray \& Tilley, Nick (1997) Realistic Evaluation. London: Sage.

Payne, Malcolm (2005) Current issues in social work theory. Revista lusófona de ciências sociais 2,27-38.

Pitkänen, Tuuli \& Kaskela, Teemu \& Tyni, Sasu \& Tourunen, Jouni (2016) Päihdehoitoon hakeutuneiden rikollisuus. Rekisteri- ja hoitotietoihin perustuva seurantatutkimus vankeusrangaistukseen tuomituista päihdehoidon asiakkaista. Rikosseuraamuslaitoksen julkaisuja 1/2016. Helsinki: Rikosseuraamuslaitos.

Päihdehuoltolaki 1986/41. Finlex.

Päihdetyön linjaukset vuosille 2012-2016. (2012) Helsinki: Rikosseuraamuslaitos.

Rantanen, Teemu \& Toikko Timo (2014) Näyttöön perustuva käytäntö: suomalaisen rikosseuraamusalan keskustelun ja sosiaalityökeskustelun vertailua. Teoksessa Henrik Linderborg, Mari Suonio \& Tytti Lassila (toim.) Sosiaalityö ja sosiaalinen tuki rikosseuraamusalalla. Rikosseuraamuslaitoksen julkaisuja 1/2014. Helsinki: Rikosseuraamuslaitos, 113-135.

Rikosseuraamuslaitoksen strategia 20112020.Rikosseuraamuslaitos.http://www. rikosseuraamus.fi/material/attachments/ rise/risenasiakirjoja/6A3hglF5q/Risen_strategia_2011-2020.pdf. Luettu 29.3.2017.

Rikosseuraamuslaitoksen tilastoja 2016 (2017) Helsinki: Rikosseuraamuslaitos.

Rikosseuraamuslaitos. Yhdyskuntaseuraamustoimistot. http://www.rikosseuraamus.fi/fi/index/toimipaikatjayhteystiedot/yhdyskuntaseuraamustoimistot. html. Luettu 18.10.2017

Saarnio, Pekka (2001) Mitkä tekijät vai- 
kuttavat terapiasuhteen keskeyttämiseen avopäihdehoidossa? Yhteiskuntapolitiikka 66 (3), 224-232.

Schwedler, Andreas \& Woessner, Gunda (2017) Identifying the rehabilitative Potential of Electronically Monitored Release Preparation: A Randomized Controlled Study in Germany. International Journal of Offender Therapy and Comparative Criminology 61 (8), 839-856.

Seppänen, Laura \& Heikkilä, Heli \& Kira, Mari \& Lallimo,Jiri \& Ruotsala, Riikka \& Schaupp, Marika \& Toiviainen, Hanna \& Uusitalo, Hanna \& Ala-Laurinaho, Arja (2014) Palveluverkostojen muuttuvat toimintakonseptit. Asiakasymmärrys, välineet $\mathrm{ja}$ työhyvinvointi verkostoyhteistyössä. Tampere: Työterveyslaitos.

Tyni, Sasu (2015) Vankeinhoidon vaikuttavuus. Onko kuntoutukselle tilastollisia perusteita? Väitöskirja. Rikosseuraamuslaitoksen julkaisuja 1/2015. Helsinki: Rikosseuraamuslaitos.
Vanhaelemeesch, Delphine \& Beken, Tom Vander \& Vandevelde, Stijn (2014) Punishment at home: Offenders' experiences with electronic monitoring. European Journal of Criminology 11 (3), 273-287.

Vankeuslaki 2005/767. Finlex.

Viikki-Ripatti, Sari (2011) Rikollisuudesta irrottautuminen subjektiivisena kokemuksena. Teoksessa Raino Lavikkala \& Henrik Linderborg (toim.) Rikosseuraamustyön kehittämisen kysymyksïa. Acta Poenologica 2/2011, Vantaa: Rikosseuraamusalan koulutuskeskus, 197-226.

Wild, T. Cameron \& Cunningham, John A. \& Ryan, Richard M. (2006) Social pressure, coercion, and client engagement at treatment entry: A self-determination theory perspective. Addictive Behaviors 31 (10), 1858-1872. 


\section{LIITE 1}

Taulukko 1: Haastateltavat

\section{Asiakkaat (n=12)}

- Kaikkien valvotun koevapauden toimeenpanosuunnitelmaan on sisältynyt päihdekuntoutus.

- Kaikki miehiä, ikä keskimäärin 42 vuotta.

- Kahdella pääpäihteenä oli alkoholi, yhdellä peliriippuvuus ja yhdeksällä huume- ja sekakäyttö.

- Kolme haastateltavista oli ollut korvaushoidossa.

- Kaksi oli tai oli ollut valvotun koevapauden aikana ympärivuorokautisessa päihdehuollon laitoshoidossa tai asumispalvelussa, kahdeksan intensiivisessä avopäihdekuntoutuksessa ja kaksi muussa avopäihdekuntoutuksessa (A-klinikka).

- Yksi oli ensikertalainen vankilassa, neljä yli kymmenen kertaa vankilassa olleita ja yksi jopa 20 kertaa.

- Viisi oli haastatteluhetkellä valvotussa koevapaudessa ja päihdekuntoutuksessa, seitsemälle se oli päättynyt.

\section{Päihdetyöntekijät (n=12)}

- Työkokemus päihdetyössä oli 5 - 25 vuotta, keskimäärin 16 vuotta.

- Osalla oli paljon kokemusta valvotusta koevapaudesta jo useamman vuoden ajalta ja osalla kokemusta vain yhden tai muutaman koevapaudessa olevan asiakkaan kanssa.

- Viisi työskenteli ympärivuorokautisessa päihdehoitolaitoksessa tai päihdehuollon asumispalveluissa ja seitsemän avopäihdekuntoutuksessa (kaksi intensiivisessä avopäihdekuntoutuksessa).

- Kaikki edustivat järjestösektoria. 